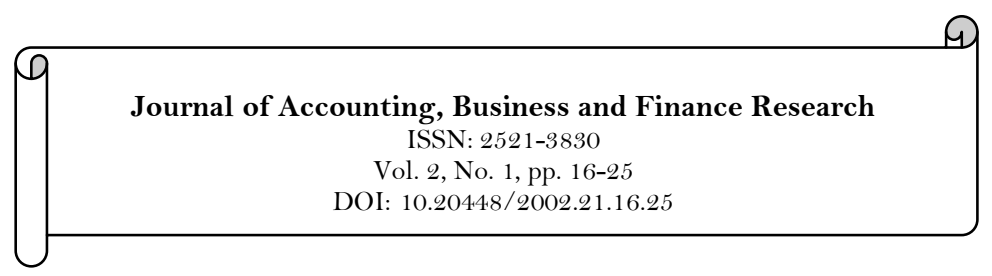

\title{
Financial Condition, Growth, Audit Quality and Going Concern Opinion: Study on Manufacturing Companies Listed on Indonesia Stock Exchange
}

\author{
Mukhtaruddin ${ }^{1}$ \\ Handri Pratama ${ }^{2}$ \\ Inten Meutia ${ }^{s}$ \\ 1,2,3Accounting Department, Economics Faculty, Sriwijaya University, Palembang, Indonesia. \\ Email:yuditz@yahoo.com
}

\begin{tabular}{|c|c|}
\hline Abstract & \\
\hline $\begin{array}{l}\text { Going concern audit opinion is accepted by the company represents } \\
\text { the presence of conditions within the auditor doubts of the company's } \\
\text { going concern. Going concern audit opinion can be used for the users } \\
\text { of the financial statements in making investment decisions in a } \\
\text { company. This study examines the effect of the company's financial } \\
\text { condition, company's growth, and audit quality on acceptance of } \\
\text { going concern audit opinion. This research uses } 252 \text { sample of } \\
\text { manufacturing companies listed in Indonesia Stock Exchange (IDX) } \\
\text { in } 2010-2012 \text {. The hypotheses in this research investigated using } \\
\text { logistic regression. The hypothesis testing showed that company's } \\
\text { financial condition influence the acceptance of the going concern } \\
\text { audit opinion, while company's growth and audit quality do not } \\
\text { influence the acceptance of going concern audit opinion. So the } \\
\text { limitation of this research is this research only on manufacturing } \\
\text { company the writer hope in the next research could do a research in } \\
\text { a different sector for showing a consistency research result. }\end{array}$ & $\begin{array}{l}\text { Keywords: } \\
\text { Going concern opinion } \\
\text { Financial condition } \\
\text { Company's growth } \\
\text { Audit quality. } \\
\text { JEL Classification: } \\
\text { M42, M41, K22, G30. } \\
\text { Licensed: } \\
\text { This work is licensed under a } \\
\text { Creative Commons Attribution } \\
\text { 4.0 License. } \\
\text { Publisher: } \\
\text { Scientific Publishing Institute }\end{array}$ \\
\hline
\end{tabular}

1. Introduction

1.1. Background

The financial report is one of the important tools used by companies to communicate a company's financial condition. In the Statement of Financial Accounting Standards 1 explained that the primary objective of financial reporting is to provide information that concerns the financial position of an enterprise that is useful for a large number of users in making economic decisions and shows the work done by management or management stewardship the use of resources that are entrusted to him. Providing high-quality information is important for an organization because it will affect investors in making investment decisions where it will provide a positive influence for the organization.

In order to enhance investor confidence in the quality of information in the financial statements, the company conducted an audit of financial statements. Both audits conducted by the internal audit of the company itself or a public accounting firm. A company that went public are required to conduct an independent audit conducted by auditors who work in Public Accounting Firm (PAF). In performing its duties the auditor express an opinion on the fairness, in all material respects, the financial position, results of operations, changes in equity and cash flows in accordance with Generally Accepted Accounting Principles (GAAP) in Indonesia.

In addition to obtaining information about the fairness of the financial statements, the independent auditor's report also provides information to users of financial statements regarding the company's ability to continue its business (going concern). Going concern is also called continuity assumption which is a business accounting estimates will continue in an unlimited time period (Syahrul, 2000). The users of the financial statements feel spending going concern audit opinion as a corporate bankruptcy prediction. Spending going concern opinion is very influential for the users of financial statements to make the right decisions in investing, because when an investor will make an investment he needs to know the financial condition of the company, especially concerning the survival of the firm (Hany \& Mukhlasin, 2003).

Problems arise when many errors made by the auditors opinion regarding the going concern opinion (Barry, 2003). Some of the problem, among others, (1) Issues self-fulfilling prophecy which states that if the 
auditor gives going concern opinion, the company would be quickly bankrupt because many investors or creditors are cancalling an attractive investment funds (Venuti, 2007), and (2) does not the presence of going concern status determination procedures are structured (Joanna, 1994) because there is almost no clear guidance or existing research that can be used as a reference selection of the type of going concern opinion to be selected (LaSalle \& Anandarajan, 1996). It is not easy for the auditors give going concern opinion for a company because of the condition of a company is affected by factors which the company operates both factors from within and outside the company. In this study, researchers distinguish factor it into the company's financial condition, growth, and quality auditor.

Ross, Randolph, and Jeffrey (1999) revealed that the bankruptcy can be seen indications of whether the company is experiencing financial difficulties (financial distress), a condition in which the company experienced operating cash flow sufficient to meet all current liabilities. Financial difficulties will result in the company having negative cash flow; financial ratios are poor and cannot pay the debt agreement. In the end, the financial difficulties this will lead to bankruptcy so that the going concern status of the company in question. At the company level are found ill health problems going concern. According to Santosa and Linda (2007) states that the disturbed or deteriorated condition of the company, the more likely the company will receive a going-concern audit opinion. In contrast to companies that have never experienced financial difficulties auditors have never issued a going-concern audit opinion.

The financial condition presented the company's healthty level in financial aspect (Ramadhany, 2004). McKeown, Mutchler, and Hopwood (1991), Santosa and Linda (2007) state that the disturbed or deteriorated condition of the company, the more likely the company received a going concern audit opinion. This is consistent with empirical evidence that states that the greater the profitability of the company received a going concern audit opinion (Praptitorini \& Januarti, 2007; Ramadhany, 2004) and otherwise in good financial condition of the company, then it is likely to receive a going-concern audit opinion will be smaller.

The company's growth can be seen from how well the company maintain its economic position in the industry and overall economic activity (Setyarno, Indira, \& Faisal, 2006). Companies that have good growth tends to make a profit so the potential to get a reasonable opinion of the auditor greater. Companies with negative growth indicate a greater tendency towards backrupt (Santosa \& Linda, 2007).

Quality auditors based on the auditor's trust of service users. Auditor reputation is often used as a measure of quality auditors, however, the research competency and independency is still rarely used to see how the actual quality auditor (Ruiz-Barbadillo, Gómez-Aguilar, \& Carrera, 2009). Mutchler, Hopwood, and Mckeown (1997) found evidence that the big 6 auditors tend to give opinion on the going concern companies experiencing financial distress than non-Big 6 auditors The larger the scale, the greater the likelihood of auditors issuing going concern audit opinion.

The author chose firms from the manufacturing industry as the research object because the company according to the IDX in 2011 as many as 129 companies listed in IDX. While the number of all types of companies listed on the IDX in 2011 amounted to 451 companies. This means that approximately 29.04\% of the companies listed in IDX is a manufacturing company. The manufacturing company also is a provider of primary and secondary needs for the community that also has an important role in the economy. Manufacturing companies tend to have more complex operations than firms in other industries.

Based on this background the researcher is motivated to do research again about the factors that affect the going concern audit opinion that the company's financial condition, growth, and quality auditor. This study is a replication of study conducted by Yuniar (2010). Yuniar (2010) examines the factors that affect the company going-concern audit opinion. The difference of this study to Yuniar (2010) in Yuniar (2010) the company's growth is measured using Tobin's $Q$, while in this study the growth of the company measured by sales growth proxy. In addition, this study started from the year 2010-2012 on the grounds that the companies that have gone public have grown since the economic crisis of 2008. This study also adds financial condition variables and the predicted growth of the company can influence the audit opinion going concern.

Based on the description of the background of the above problems, it can be formulated research problem is how the company's financial condition, the growth of the company and affect the quality of the auditor's going-concern audit opinion companies listed in IDX during the period 2010-2012?

\section{Literature Review}

\subsection{Agency Theory}

Agency theory is the basis of the theory underlying the company's business practices are used for this. The theory stems from the synergy of economic theory, decision theory, sociology, and organizational theory. The main principle of this theory suggested a working relationship between the parties which gives authority (principal) is the investor with the party receiving authority (agency) that the manager, in the form of cooperation contract called a "nexus of contracts". Jensen and Meckling (1976) define an agency relationship as a contract in which one or more persons (the principal) requesting the other party (the agent) to carry out some work on behalf of the principal which involves some decision-making authority to the agent. This theory assumes that all individuals acting on their own free will in this case if both parties involved in the partnership seeks to increase profits or the value of them there is a possibility that the agent will not act to the fullest for 
the benefit of the principal. With the aim to improve the performance of the principal agent contract to design in such a way so as to accommodate the interests of all parties involved. Efficient contract is a contract that satisfies both assumptions that (1) agents and principals have symmetric information means that both the agent and the principal have the same amount and quality of the information together so that both parties are equally not take advantage for himself, and (2) the risk borne by the agent is associated with a small return on their services which means the agent has a high certainty of return.

However, in reality the agent as the manager of the company knows a lot more about the information that is in the company compared with the principal as the owner of the company so that it creates information asymmetry. Eisenhardt (1998) states there are three assumptions related to agency theory of human nature, namely: (1) humans are mostly selfish man, (2) humans have limited thinking about the future, and (3) people are always trying to avoid risk. Based on the assumption that human nature tends managers will act optimistic, which in this case priority to personal interests and will certainly lead to conflicts that the agency is required to deal with an independent auditor in charge of financial management to evaluate and give an opinion on the fairness of financial statements presented by management. As independent party, auditors required to conduct monitoring of the performance of the company whether it has acted in accordance with the principals through the financial statements. Auditor's duty to provide a fairness opinion the financial statements of the company and also reveals the problems faced by the company's going concern when the auditors doubt the ability of a company to survive.

\subsection{Audit Opinion}

The auditor as an independent party in the examination of the financial statements will provide a statement of opinion on the financial statements audited. Auditor's report is a means for the auditor to express his opinion, or if circumstances require to express no opinion. According to Halim (2008) there are five types of opinion can be given by the auditor, namely (1) an unqualified opinion, (2) an unqualified opinion with explanatory language, (3) a qualified opinion, (4) adverse opinion, and (5) disclaimer of opinion.

\subsection{Going Concern Audit Opinion}

Going concern is one of the most important concepts underlying financial reporting is about the survival of a business entity. This concept assumes that an enterprise that will continue to live in terms of liquidation is not expected to occur in the future. Hany and Mukhlasin (2003) suggested that when auditors check the financial condition of a company in the annual audit, the auditor must provide an audit report to be combined with the company's financial statements. One of the important things that must be decided is whether the company can sustain life (going concern). Rahayu (2007) states that the term going concern can be interpreted in two ways, the first is as a going concern concept and the second is as a going concern audit opinion. As a concept, the term can be interpreted as a going concern going concern ability of the company in the long run. As the audit opinion, the term going concern opinion addressing the auditor has doubts about the company's ability to continue its business in the future.

Ways that are often used to evaluate the presence of the auditor doubts about the going concern status of the company (1) The auditor considers whether the results of the procedures performed in planning the audit evidence collection and prosecution, may identify circumstances or events as a whole, and (2) If the auditor believes that there are doubts the company's ability to survive in a reasonable period of time, the auditor should (a) Obtain information on the management plan be referred to reducing the impact of such conditions and events, (b) Determine whether the likelihood that the plan can be effectively implemented, and (c) after auditors evaluate management plan, it can be concluded going concern status of a company or not.

According to Altman and McGough (1974) issue of going concern is divided into two, namely: financial issues that include financial (deficiency) liquidity, equity deficiency, delinquent debt, difficulties in obtaining funding, as well as operating problems which include loss of continuous operation, the earnings outlook doubt, operation ability is threatened, and weak control over the operation. The auditor should consider the results of operations, economic conditions affecting the company, the ability of debt payments, and liquidity needs in the future (Lenard, Alam, \& Booth, 1998). Arens and Loebecke (2006) states there are several factors that can lead to uncertainty over the company's ability to maintain its viability, namely (1) The occurrence of operating losses or a significant working capital deficiency, (2) inability of the company to pay obligations maturity, (3) Loss of the main customer, flood disaster not covered by insurance, such as earthquake or flood, or a labourr problems are not common, and (4) the court, statutory, or other similar things can threaten the ability of the company's operations.

According to Muchler, Renz, and Ludecke (1985) criteria that the company will receive a going concern opinion if the company has problems in revenue, reorganization, the failure to pay interest, received a going concern opinion prior year, in the process of liquidation, capital is negative, negative cash flow, negative working capital, 2-3 years consecutive loss, and negative retained earnings. From the above presentation it can be understood as a going concern, which assumes that the company postulate considered being live and operational for an indefinite period of time if there are no signs or definite plan the company will be dissolved. 


\subsection{Hypothesis Development}

\subsubsection{Financial condition and Going Concern Audit Opinion}

The financial condition of the company describes the level of health of the company in fact. In companies that are not healthy financial condition indicators are found going concern problem. This condition is described from the financial ratios that can give an indication of whether the company is in good shape or in bad shape. The company has a healthy high profitability and tend to have a reasonable financial statement so the potential to get a good opinion will be greater than if the low profitability (Petronela, 2004). According Sartono (2008) which includes a financial analysis of financial ratio analysis, analysis of weaknesses and strengths in finance will greatly assist the management of the past and the future prospects. With this financial analysis can be known strengths and weaknesses of the company. This ratio can give an indication of whether the company has sufficient cash to meet its financial obligations, the amount of receivables is quite rational, efficient inventory management, good planning and investment expenditures healthy capital structure so that the goal of maximizing shareholder wealth can be achieved. The soundness of a company can be seen from the company's financial condition. Companies that have good financial condition, the auditor will not issue a going concern audit opinion (Ramadhany, 2004). Setyarno et al. (2006) using logistic regression showed that the variables that proxy the financial condition of The Altman model significantly influence the going-concern audit opinion. The results of this study are consistent with Ramadhany (2004) provide evidence that auditors almost never give going concern audit opinion on the company that is not experiencing financial difficulties.

Some previous studies concluded that the prediction model defaults using financial ratios are more accurate than the auditor's opinion in classifying bankrupt and not bankrupt companies (Altman \& McGough, 1974; Koh \& Killough, 1990) and based on this description the first hypothesis is H1: the financial condition of the company (measured by the Altman Model) has negatively affect the going-concern audit opinion.

\subsection{The growth of the company and Going Concern Audit Opinion}

The company's growth indicates a company's ability to maintain its survival. The company's growth can be proxy by the ratio of sales growth. This ratio measures how well the company maintain its economic position, both in industry and in the overall economic activity (Setyarno et al., 2006). The company is experiencing growth shows the operational activities of the company running properly so that the company can maintain its economic position and survival. While firms with negative sales growth ratio decreased potentially huge profits that management needs to take corrective action in order to maintain their survival. The company's sales increased from year to year, giving the company the opportunity to obtain an increase in profit. Therefore, the higher the ratio of the company's sales growth will be the less likely the auditor to issue a going concern audit opinion (Setyarno et al., 2006).

In this study the company's growth is proxy by the ratio of sales growth. Weston and Copeland (1992) suggested that this ratio measures how well the company maintain its economic position both in industry and in the overall economic activity. A company with a positive sales growth ratio gives an indication that the company is better able to maintain their life and the possibility of bankruptcy of the company is small. Therefore, the higher the growth rate the company's growth, it will be the less likely the auditor to issue a going concern audit opinion.

The company is experiencing growth shows the operational activities of the company running properly so that the company can maintain its economic position and survival, while firms with negative growth indicates a greater tendency towards bankruptcy. Based on this description, the second hypothesis is $\mathrm{H} 2$ : company growth has negatively affected the going concern audit opinion.

\subsection{Audit Quality and Going Concern Audit Opinion}

Audit quality is defined by each person differently because of the audit quality is not a clear meaning. However, the users of the financial statements found audit quality when the auditor is to ensure there is no error in the financial statements. Financial statement users typically associate with a reputation for quality audit an auditor. Craswell, Francis, and Taylor (1995) stated that clients usually perceive that auditors from the firm that is large and has an international affiliation with the firm will have a higher quality because the auditors have characteristics that can be associated with quality, such as: training, international recognition, and the presence of peer review. Auditors who have a good reputation will strive to maintain the quality of audit shopped it so it does not lose the trust of clients.

Deis and Giroux (992) conducted a study on four things are considered to have a relationship with audit quality, namely (1) the length of time the auditor has conducted an examination (tenure), the longer the auditor has audited, the quality of the resulting audit would be lower, (2) the amount auditor, the more the number auditor, the audit quality will get better as the number of auditors to maintain its reputation, (3) financial health, the healthier financial condition then there will be the tendency to suppress the auditor to not follow the standards, and (4) a review by a third party, audit quality will increase if the auditor is aware that the results of his work will be reviewed by a third party. De Angelo (1981) defines audit quality as the probability that an auditor to find and report on the existence of a breach in the accounting system. The 
results showed that the PAF) were most likely trying to present a greater quality audits compared with small public accounting firm. Palmrose (1988) proved in his research that the group auditor litigation Big 8 has a low level compared to non-big 8, it shows that Big 8 auditors provide higher quality because it has the motivation to maintain his reputation. Suharli and Oktorina (2005) stated that large-scale auditors are also more likely to reveal the problems that exist because they are stronger to face the risk of litigation. That argument means that the auditor has a large-scale intensive for detecting and reporting of going concern issues of its clients.

Audited financial statement is resulting quality of the audit conducted by qualified auditors. Financial statement users more confidence in the financial statements audited by the auditor of high quality because financial statement users believe that auditors will be more careful in conducting audits to maintain its credibility. The auditor is responsible for providing information that has high quality for users of financial reports. Auditors who have a good quality audit will issue a going concern audit opinion when the client involved regarding a going concern problem. De Angelo (1981) concluded that the larger the firm can be interpreted generate audit quality better than a small PAF, the large scale of PAF is also more likely to reveal problems experienced by clients because they are more robust in the face litigation.

This hypothesis is supported by Fanny and Saputra (2005) who found evidence that the firm that has a good reputation they will maintain its reputation. The auditor will give the company a going concern or predicted experiencing difficulties leading to bankruptcy. Based on these descriptions, the third hypothesis is H3: Quality audits positive effect on going-concern audit opinion

\subsection{Theoretical Framework}

This study was conducted to examine the effect of the company's financial condition, growth, and quality audit of going concern audit opinion on companies listed on IDX which can be described in terms of the following diagram:

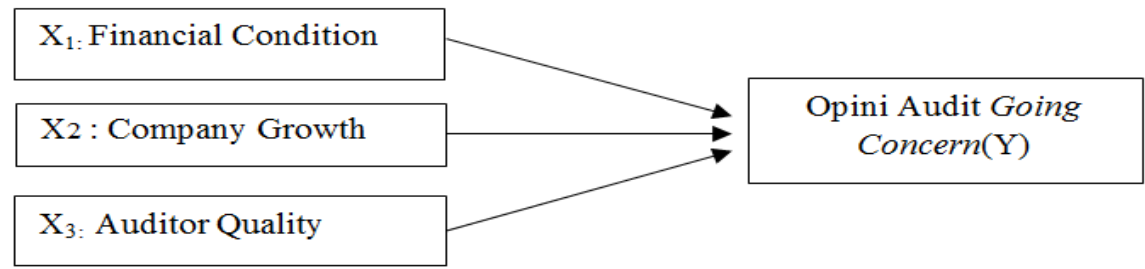

Source: Yuniar (2010) (Modified).

Figure-1. Theoretical Framework.

\section{Research Methodology}

\subsection{Population and Sample}

This study used a population of manufacturing companies that publishes financial statements of the company in 2010-2012, and listed on the IDX. Sampling techniques to select of sample is purposive sampling, the type of sampling is not random that the information obtained by using certain considerations and is generally tailored to the research problem (Indriantoro \& Bambang, 2002). This sampling method chosen in the hope of representing the population and does not cause bias for research purposes. Research determines three criteria for the sample to be selected. Based on predetermined criteria then obtained as much as 84 samples, so that the numbers of observations are 83 firms x 3 year's observation of the 252 observations.

\subsection{Operational Definitions of Variables 3.2.1. Going Concern audit Opinion}

Going concern audit opinion is modified audit opinion that the auditor's judgment. There is an inability or significant uncertainty over the viability of the company in running its operations in the foreseeable future. Going concern audit opinion is measured using a dummy variable. Going concern audit opinion was coded 1, non-going-concern audit opinion was coded 0.

\subsection{Financial Condition}

The researchers used a model to assess the Altman model for measuring corporate bankruptcy prediction using the Altman Model covers all the company's financial condition through 22 financial ratios. Altman (1968) found that low profitability and solvency are potentially in bankruptcy. Altman (1968) developed a model of bankruptcy by using 22 financial ratios were classified into five categories: liquidity, profitability, leverage, the ratio of market tests and activities. Altman developed a model of bankruptcy by using the following model:

$$
\mathrm{Z}=1.2 \mathrm{WCTA}+1.4 \mathrm{RETA}+3.3 \mathrm{EBITTA}+0.6 \mathrm{MCBVD}+0.999 \mathrm{STA}
$$




\subsection{Company growth}

The growth of the company in this study is proxy by the ratio of sales growth (Setyarno et al., 2006). Sales growth ratio i-1 is used to measure the ability of firms in the growth rate of sales over the previous year.

\subsection{Auditor Quality}

To enhance the credibility of financial statements, companies use the services of the PAF, which has the reputation or good name. This is usually indicated by a PAF that is affiliated with a major public accounting firm that applies universally known as the Big Four PAF Worldwide (Big 4). This variable is measured by dummy variable. PAF affiliated to the Big $4 \mathrm{PAF}=1$ and non affiliated $=0$.

\subsection{Data Analysis Techniques}

Inductive statistical analysis used to test the hypothesis. In this study, the hypothesis testing is done with a multivariate analysis using logistic regression were the independent variables is a combination of metric and non-metric (nominal). This analysis technique does not require the normality test and test again the classical assumptions on the independent variable (Ghozali, 2011). Gujarati (2003) states that it is ignoring of heteroscedaticity test in logistic regression.

Logistic regression was used to examine the effect of the financial condition of the company (Z68), company growth (GROWTH), and quality auditor (AUDIT). Logistic regression models were used to test the hypothesis is as follows:

$$
\ln \frac{\mathrm{GC}}{1-\mathrm{GC}}=\alpha+\mathrm{b}_{1} \mathrm{Z} 68+\mathrm{b}_{2} \text { GROWTH }+\mathrm{b}_{3} \text { AUIDT }+\varepsilon
$$

\section{Results and Discussion \\ 4.1. Descriptive Statistics}

This study uses the companies listed in IDX as the study sample. Based on the sample criteria and procedures that have been performed Sampling acquired 84 companies with 252 years of observations in the sample. The data used in this study were taken from the independent auditor's report and financial statements of the company. The sample data indicates that the average value of going concern audit opinion indicates that the audit opinion with code 1 , the going concern audit opinion appears fewer than 252 companies studied. The average value of the financial condition of the sample studied was 5.2195341. This shows that the financial condition of the sample average to good. Seen from the large standard deviation indicates that the financial condition evenly. The average value of the company's growth indicated positive value that is equal to 0.1316304 with a minimum value of 1 and a maximum of 1.48547 . The average value of positive illustrates that the average sample firms experiencing positive growth is characterized by an increase in net sales. Minimum value of -1 indicates no sample firms experiencing negative growth, but there are also companies sample shown positive growth with a maximum value of 1.48547. Quality auditors have an average value of 0.37 , which is smaller than 0.50 indicates that the quality of the audit with code 1 , which the firm that affiliated with the Big 4 was less than 252 sample firms.

\subsection{Logistic Regression Analysis}

The data analysis was conducted using logistic regression. Ghozali (2011) states that logistic regression used to test the probability of occurrence of the dependent variable can be predicted by the independent variable. Regression models assessed the feasibility of using the Hosmer and Lomeshow Goodness of Fit Test. Hosmer and Lomeshow Goodness of Fit Test to test the null hypothesis that the data is suitable or appropriate circuitry empirical models (there is no difference only between the models with the data so that the model can be said to fit). Statistical value of Hosmer and Lomeshow Goodness of Fit Test was 0.551 with a significance probability 1 that are well above 0.05. It can be concluded that the model is able to predict the value of his observations or acceptable because it fits with the data observations. Overall assessment of the model is done by comparing the values between -2 Log Likelihood (-2LL) at the start (Block Number $=0$ ), where the model is just entering costant circuitry -2 Log Likelihood value (-22LL) at the end (Block Number $=1$ ), where models include constant and independent variables. -2LL Initial value is equal to 56,708 and the following independent variables entered, then the value of the final -2LL decreased to 22,360. This -2LL impairment showed a good regression model or in other words the hypothesized model fit the data.

The value of the coefficient of determination in logistic regression models is indicated by Nagelkerke $R$ square value. Based on the test results is shown that the value of Nagelkerke $\mathrm{R}$ square is 0.632 which means that the variability of the dependent variable that can be explained by the independent variable is equal to 63.2 percent, while the remaining 36.8 percent is explained by other variables outside the model research.

Classification table shows the predictive power of the regression model to predict the probability of going concern audit opinion by the company. The predictive power of the regression model to predict the likelihood of the dependent variable is expressed in percent. The test results show the predictive power of regression 
models for likelihood predict company received a going concern audit opinion amounted to 33.3 percent. This shows that by using the regression model, there are two companies that are expected to receive a goingconcern audit opinion. The predictive power of the regression model to predict the likelihood of the company receiving a going concern audit opinion was 99.6 percent. This means that with the regression model, there were 245 companies are predicted to receive non going-concern audit opinion.

Logistic regression model can be established by looking at the value of the parameter estimates in the Variables in the Equation. Regression models were established based on the estimated value of the parameter in the Variables in the Equation is as follows:

$$
\text { In } \frac{\text { GC }}{1-\text { GC }}=-0,010-2,237 \text { Z68 }-2,434 \text { GROWTH }-13,834 \text { AUDIT }
$$

Hypothesis testing is done by comparing the level of significance (sig.) with an error rate $(\alpha)=5 \%$. Based on the hypothesis testing results can be interpreted as follows:

- The first hypothesis (H1) stated that the company's financial condition has negatively affect to the going concern audit opinion. The test results showed that the company's financial condition (proxy by The Altman model) has a negative regression coefficient of -2.237 with a significance level of 0.003 which is smaller than $\alpha(5 \%)$. It can be conclude that the financial condition has negatively affect the going concern audit opinion, or in other words, $\mathrm{H}_{1}$ is accepted. This means that the bigger the better or the financial condition of the company, the less likely the company will receive a going-concern audit opinion.

- The second hypothesis (H2) stated that comapny growth has negatively affect to the going concern audit opinion. The test results showed that the company's growth has a negative regression coefficient of -2.434 with a significance level of 0.251 which is greater than $\alpha(5 \%)$. It can be conclude that the company's growth does not affect to the going concern audit opinion, or in other words, $\mathrm{H} 2$ is rejected.

- The third hypothesis (H3) states that audit quality has positive influence to the going-concern audit opinion. The test results show that audit quality has a negative regression coefficient of -13.834 with a significance level of 0.996 which is greater than $\alpha(5 \%)$. It can be conclude that audit qulity has no effect to the going concern audit opinion or in other words $\mathrm{H} 3$ is rejected.

\subsection{Discussion of Results}

\subsubsection{Effect of Financial Condition to Going Concern Audit Opinion}

The results showed a significant negative effect of the financial condition of the company on a going concern audit opinion. The results showed that the lower or poor financial condition, the higher the level of going-concern audit opinion. Financial condition in this study was measured by using a bankruptcy prediction model that uses the Altman Model 22 financial ratios in the model calculations. The results of this study are consistent to Solikhah (2016) which states that an auditor looks at a company's financial condition into consideration. Arens and Loebecke (2006) also mentions the factors which led to uncertainty over the company's ability to continue its survival are: the occurrence of operating losses or a significant shortage of working capital and the company's inability to pay obligations maturity.

These results are also in line with signalling theory which states that the company provide a signal to the users of financial statements as they are supposed to do (Jama'an, 2008). Financial report containing financial condition describes the financial condition clearly so that it can be used by the auditor in the provision of audit opinion. The good of financial statements condition if it is free from problems of liquidity, has sufficient working capital, and has a high equity would not get going-concern opinion contrary to the company's financial statements to the poor financial condition tend to receive a going-concern audit opinion.

Altman and McGough (1974) also stated that the issue of going concern is divided into two, namely the financial problems which include lack of liquidity, equity deficiency, delinquent debt, difficult obtain of funds, as well as operating problems which include loss of continuous operations, earnings outlook dubious, the ability to control the operation of threatened and weak on operations. This hypothesis is supported in line with research conducted by Setyarno et al. (2006). These results are also supported by Ramadhany (2004), Fanny and Saputra (2005), Mutchler et al. (1997) which states that the auditor is almost never issued a going concern opinion on the companies that are experiencing financial difficulties. Basically ratio $\mathrm{Z}$ score indicates the financial condition of a company which is a warning of the threat of bankruptcy for the company. The higher this ratio indicates a state of financial condition is getting better, on the contrary, the lower this ratio indicates that the company's financial situation is getting worse

In this study the authors believe that the financial condition of a company has a high significance. An auditor of course very concerned about the financial condition of the company. A company is not experiencing serious financial problems, which is not experiencing liquidity problems, have sufficient working capital, and not run deficit equity will not acceptance of a going-concern audit opinion. In contrast, companies that experienced problems such as poor financial condition of business losses, inability to pay debt and working capital deficiency will result in the ratio $\mathrm{Z}$ score is low and as a consequence the company is likely to receive a goingconcern audit opinion due to the auditor's doubt the ability of the business unit or company the continued survival, the period of time appropriate. 


\subsubsection{Effect of Growth Company on Going Concern Audit Opinion}

The hypothesis of this studies sated the growth of the company will significantly influence to the goingconcern audit opinion. If a company had company growth (measured by the increase in sales) then the company will not receive a going-concern audit opinion. From the results, it showed that the growth of the company do not affect to the going concern audit opinion. It does not support the second hypothesis in this study. This study provides additional evidence that the growth of the company is reflected in the increase in sales does not ensure that the company does not get a going-concern audit opinion. Of the 252 samples were observed average value of a group of companies with sales growth going concern opinion and non-going concern is positive. This means that a sample of the research company experienced an increase in net sales but still receive going-concern audit opinion. This is due to the growth of the company which is proxy by sales growth does not necessarily indicate that the profits from the company also increased. The increase in operating expenses, the company will get of negative net income and reduce of retained earnings.

The results of this study are consistent with agency theory that suggested a link between managers and investors in the form of a contract of cooperation called the nexus of contract. Jensen and Meckling (1976) define an agency relationship as a contract in which one or more persons (principal) requesting the other party (the agent) to carry out some work on behalf of the principal which involves some decision-making authority to the agent. Because it is in the decision making of auditors not only consider the company's sales growth, but he should look at other conditions that favour the financial condition of the increase in profit and a decrease in corporate expenses. These results indicate that the auditor does not consider sales growth of the company in providing the going concern audit opinion due to the increase in sales is not necessarily accompanied by an increase in profit. Results were consistent with the research findings (Fanny \& Saputra, 2005) and Setyarno et al. (2006) who showed that the growth of the company has no significant effect on the going concern audit opinion.

\subsubsection{Effect of Audit Quality on Going Concern Audit Opinion}

The results of hypothesis testing showed that audit quality has no effect on the going concern audit opinion. These results do not support the third hypothesis in this study. The negative sign on the coefficient indicates that audit quality companies tend not to acquire going concern audit opinion when the company is using the services of Big 4 firm, while companies that use the services of non-Big 4 Firm will tend to get a going-concern audit opinion. Scott (2001) explains that it is a rational manager would not choose high-quality auditors and pay a higher fee if the conditions of company are not good. This opinion is based on the assumption that high-quality auditors will be able to detect the characteristics of companies that are not good and convey to the public. So it can be said that companies that use the services of Big 4 Firm is a company that has a good condition, while companies with poor performance tend to use non-Big 4 Firm in the hope that non-Big 4 Firm cannot detect that the company's performance is not good, while the side another auditor seeks to maintain its reputation by working objectively and independently. The results of this study are consistent with agency theory is that investors who accept the authority of the party in this case is the auditor as an independent party to supervise the performance of the company whether it has acted in accordance with the principal through financial statements. So Big 4 and non-Big 4 Firm will be independent and objective in issuing an audit opinion. These results are also in line with research (Setyarno et al., 2006) as well as Praptitorini and Januarti (2007) showed that audit quality had no significant effect on the going-concern audit opinion. However, these results conflict with the findings of the study (Mutchler et al., 1997) which shows that Big 6 auditors are more likely to issue a going concern audit opinion on the company experiencing financial distress.

The results of this study provide empirical evidence that audit quality was not used as a factor that can affect the going concern audit opinion. It means that the firm is affiliated with a Big 4 Firm or the Firm who is not affiliated with the Big 4 together provide a good quality audit and be independent audit opinion issued prior to the company that assessed by the auditor is unable to continue its survival.

\section{Conclusion and Recommendations}

\subsection{Conclusion}

Based on the formulation of the problem, objectives, basic theory, hypotheses and results of tests performed, it can be concluded as follows.

1. Financial condition effect to going concern audit opinion. This means the auditor to issue a going concern audit opinion consider the financial condition of the company. If companies with good financial condition, the auditor will not provide going concern audit opinion. The results of this study are consistent with research conducted by Setyarno et al. (2006); Ramadhany (2004); Fanny and Saputra (2005); (Mutchler et al., 1997) which states that the company's financial condition affects the goingconcern audit opinion

1. Company growth has not effect to company going concern audit opinion. The company's growth is proxy by sales growth. These results indicate that the auditor does not consider sales growth in providing the going concern audit opinion because the increasing sales are not necessarily accompanied 
by an increase in profit. Results were consistent with the research findings Fanny and Saputra (2005) and Setyarno et al. (2006) who showed that the growth of the company has no significant effect on the going concern audit opinion.

2. Quality of audits has no effect on going concern audit opinion. This means that the firm is affiliated with a Big 4 Firm or the Firm is not affiliated with the Big 4 together provide a good quality audit and are independent in providing a going concern audit opinion. The results of this study are consistent to Setyarno et al. (2006), as well as Praptitorini and Januarti (2007) indicates that audit quality had no significant effect on the going-concern audit opinion.

\subsection{Suggestion}

Several limitations affect the research and development necessary to take the next researcher. The suggestions that can be delivered by this study are as follows:

1. The coefficient of determination $\mathrm{R}$ square) is equal to 0.632 which means that the variability of the dependent variable that can be explained by the independent variable is equal to 63.2 percent, while the remaining 36.8 percent is explained by other variables outside the model study. This means that there are other variables that need to be identified to explain the going-concern audit opinion. Another variable that can theoretically affect the going concern audit opinion that debt default, corporate governance mechanisms, opinion shopping, and implementation of management strategies. Therefore, subsequent research can consider the other variables and these variables can be tested with different analytical techniques.

2. This study was only done on companies listed in IDX; subsequent research can conduct research with different objects such as a financial sector company to obtain the consistency of the results of research.

\section{References}

Altman, E. I. (1968). Financial ratios, discriminant analysis and the prediction of corporate bankruptcy. The Journal of Finance, 23(4), 589-609.

Altman, E. I., \& McGough, T. P. (1974). Evaluation of a company as a going concern. Journal of Accountancy, 138(6), 50-57.

Arens, A. A., \& Loebecke, J. K. (2006). Auditing: Integrated approach. Book one. English Edition. Jakarta: Amir Abadi Jusuf's Translation. Salemba Four.

Barry, S. (2003). Effect of audit expertise and independence of the opinion audit. Accounting Research Journal of Indonesia, 6(1), 1-22.

Craswell, A. T., Francis, J. R., \& Taylor, S. L. (1995). Auditor brand name reputations and industry specializations. Journal of Accounting and Economics, 20(3), 297-322.

De Angelo, L. E. (1981). Auditor size and audit quality. Journal of Accounting and Economics, 3(3), 183-199.

Deis, J. D. R., \& Giroux, G. A. (992). Determinants of audit quality in the public sector. Accounting Review, 67, 462-479.

Eisenhardt, K. M. (1998). Agency theory: An assessment and review. Academy of Management Review, 14(1), 57-74.

Fanny, M., \& Saputra, S. (2005). Audit opinion going concern: Assessment based on prediction model of bankruptcy, corporate growth, and public accountant reputation (Study in Stock Exchange Issuer Jakarta). Solo: National Symposium on Accounting VIII.

Ghozali, I. (2011). Application of multivariade analysis with SPSS program. Semarang: Dipenogoro University Publishing Agency.

Gujarati, D. (2003). Basic econometrics. New York: McGraw Hill.

Halim, A. (2008). Auditing (Audit Basics of Financial Statements) (4th ed., Vol. 1). Yogyakarta: UPP STIM YKPN.

Hany, C., \& Mukhlasin. (2003). Going concern and audit opinion: A study on banking companies in BEJ. Surabaya: National Symposium on Accounting VI.

Indriantoro, N., \& Bambang, S. (2002). Business research methodology (2nd ed.). Yogyakarta: BPFE.

Jama'an. (2008). Influence of corporate governance mechanism, and quality of public accounting firm against information integrity of financial statements (Case Studies of Public Companies Listed on BEJ). Thesis, Dipenegoro University.

Jensen, M. C., \& Meckling, W. H. (1976). Theory of the firm: Managerial behavior, agency costs and ownership structure. Journal of Financial Economics, 3(4), 305-360.

Joanna, H. L. (1994). The effect of experience on consensus of going-concern judgments. Behavioral Research in Accounting, $6,160-177$.

Koh, H. C., \& Killough, L. N. (1990). The use of multiple discriminant analysis in the assessment of the going-concern status of an audit client. Journal of Business Finance Eं Accounting, 17(2), 179-192.

LaSalle, R. E., \& Anandarajan, A. (1996). Auditors' views on the type of audit report issued to entities with going concern uncertainties. Accounting Horizons, $10(2), 51-72$.

Lenard, M. J., Alam, P., \& Booth, D. (1998). An analysis of fuzzy clustering and a hybrid model for the auditor's going concern assessment. Decision Sciences, 31(4), 861-884.

McKeown, J. C., Mutchler, J. F., \& Hopwood, W. (1991). Towards an explanation of auditor failure to modify the audit opinions of bankrupt companies. Auditing-a Journal Of Practice \& Theory, 10, 1-13.

Muchler, H., Renz, D., \& Ludecke, D. (1985). Anesthetic management of acromegaly. Paper presented at the Neuroendocrinology Letters.

Mutchler, J. F., Hopwood, W., \& McKeown, J. M. (1997). The influence of contrary information and mitigating factors on audit opinion decisions on bankrupt companies. Journal of Accounting Research, 35(2), 295-310. Available at: https://doi.org/10.2307/2491367. 
Palmrose, Z.-V. (1988). 1987 competitive manuscript Co-winner: An analysis of auditor litigation and audit service quality. Accounting Review, 63, 55-73.

Petronela, T. A. (2004). Consideration of going concern of companies in giving opinion of audit. Balance, 46-55.

Praptitorini, \& Januarti. (2007). Analysis of the effect of audit quality, debt default, and opinion shopping on the acceptance of going concern opinion. Makasar: National Symposium on Accounting X.

Rahayu, P. (2007). Assessing going concern opinion: A study based on financial and non financial information. Makassar: Simposium Nasional Akuntansi X.

Ramadhany, A. (2004). Analysis of factors affecting opinion opinion going concern in manufacturing companies that experienced financial distress in Jakarta stock exchange. Thesis, Master Program in Accounting Diponegoro University, Semarang.

Ross, S. A., Randolph, W. W., \& Jeffrey, J. (1999). Corporate finance (5th ed.). Irwin Mc: Graw-Hills.

Ruiz-Barbadillo, E., Gómez-Aguilar, N., \& Carrera, N. (2009). Does mandatory audit firm rotation enhance auditor independence? Evidence from Spain. Auditing: A Journal of Practice \& Theory, 28(1), 113-135.

Santosa, A. F., \& Linda, K. W. (2007). Analysis of factors affecting the concerns of opinion audit going concern. Scientific Accounting Journal, 11(2), 141-158.

Sartono, A. (2008). Financial management theory and applications. Yogyakarta: BPFE Yogyakarta.

Scott, W. R. (2001). Financial accounting theory. Canada: Ontario: Prentice Hall Inc.

Setyarno, E. B., Indira, J., \& Faisal. (2006). Influence of audit quality, company's financial condition, audit opinion of the previous year, corporate growth on going concern audit opinion. Padang: National Symposium on Accounting IX.

Solikhah, B. (2016). Auditor's consideration in providing going concern audit opinion. Equity: Journal of Economics and Finance, 20(2), 129-150.

Suharli, M., \& Oktorina, M. (2005). Predicting investment returns on equity securities through profitability ratios, liquidity and debt to public companies in Jakarta. Solo.: National Symposium on Accounting VIII.

Syahrul. (2000). Accounting dictionary. Jakarta: Citra Harta Prima.

Venuti, E. K. (2007). The going concern assumption revisited: Assessing a company's future viability. The CPA Journal Online, 1-5.

Weston, J. F., \& Copeland, T. E. (1992). Managerial finance (9th ed.): The Dryden Pres.

Yuniar. (2010). Effect analysis on firm size, company financial condition, audit opinion of the previous year, company growth and company size on audit opinion going concern: Case study on manufacturing companies listed on BEI 2003-2008. Thesis, Sebelas Maret University, Surakarta. 